\title{
The contemporary cartographic presentation of geographical names of objects lying on the border between Poland and the Czech Republic
}

\begin{abstract}
The aim of this paper is the analysis of the names used on cartographic publications in Poland and the Czech Republic for transboundary geographical objects lying on the common boundary.

After the analysis of the Czech and Polish topographic maps that are available on the national geoportals, maps of the divisions into natural regions, and toponymic databases (Polish the National Register of Geographical Names, and Czech Geonames - the Database of geographic names of the Czech Republic) it was established that 360 named geographic objects lie on this boundary. This number includes: 123 hydronyms (names of rivers and other streams), 224 oronyms (139 names of summits, 22 names of mountain passes, 35 names of mountain ranges and ridges, 15 names of highlands, plateaus and uplands, 7 names of mountain basins, valleys and depressions, 3 names of lowlands, and 3 names of rocks), 9 names of forests, 1 name of mountain meadow (alp), and 3 names of tracks.

212 of these objects (59\%) have names in both languages - Polish and Czech, however, in 99 cases (47\% of objects that have name in both Polish and Czech languages) the Polish and Czech toponyms entirely do not correspond to each other. From the remaining objects $67(18 \%)$ have only the Czech name, and $81(23 \%)$ only the Polish name. In some natural regions, the limits of their ranges set by the Czech and Polish geographers vary widely, for example a single region on one side of the boundary corresponds to two or more regions on other side of the boundary. In other cases illustrations of incorrectness are more sophisticated, like the river that has different course according to the Czech or Polish maps (stream regarded as a main watercourse in one country, which has its own name, in another country is considered as a tributary one with a different name).

In the summary, it should be stated that in the large part of the Polish and Czech names of the geographical objects lying on the common boundary were drawn regardless of the names used in the neighboring country.
\end{abstract}

Keywords: transboundary name, topographic map, register of geographical names, Polish-Czech boundary

\section{Introduction}

Each country which has land borders also has geographic objects exceeding beyond its borders, such as watercourses, lakes, plains, lowlands, and mountain ranges. They are objects exceeding the sovereignty of one country (transboundary objects ${ }^{1}$ ), both from the territorial perspective and the onomastic perspective. If such objects were named, different names can be used on both sides of the border, which

\footnotetext{
${ }^{1}$ In this context we can also talk about objects lying on the national border - they are small objects located on the border, which can be treated as point objects, e.g. a summit, a pass, a rock.
}

especially applies to official names that has been approved by a relevant authority responsible for geographic names in a given area. In such cases we deal with a transboundary name (N. Kadmon 2014, p. 56).

In the case of names of transboundary objects, we can come across a situation when the same language is used on both sides of the border (e.g. the border between Germany and Austria), and, therefore, the same names may be used on both sides of the border. More frequently, especially in Europe, we have situations when two different official languages are used on both sides of the border. In such cases, using different names on both sides of the border is much more probable, e.g. generic 
elements of toponyms are presented in the language used on a given side of the border. In the case of Poland, a change of the official language takes place crossing each land border. The languages include Russian, Lithuanian, Belarusian (with Russian as the second official language), Ukrainian, Slovak, Czech and German. In this article, names of transboundary objects located on the border between Poland and the Czech Republic were analyzed.

\section{Border between Poland and the Czech Republic}

Poland shares land borders with seven countries, and their total length is $3,071 \mathrm{~km}$. The longest section, which length is $796 \mathrm{~km}$, constitutes the border with the Czech Republic (Mały Rocznik Statystyczny Polski 2014, p. 26). This border has its western beginning in the Nysa River valley at the foothills of the Sudety Mountains and then goes through the Sudety Mountains, southern edges of the Silesian Lowland [Nizina Śląska], the foothills of the Carpathians [Karpaty] and the Carpathians itself (Beskidy Zachodnie). Therefore, it goes mainly through mountain and foothill areas, and, in a small area, also through plateaus and valleys (Polska. Mapa... 2011); the lowest point on the border, the mouth of the Olza River into the Odra River, is at $188.5 \mathrm{~m}$ above sea level (Mapa topograficzna... 1987), while the highest point, Śnieżka (Sněžka), is at $1,603.3 \mathrm{~m}$ above sea level according to the latest Czech measurements (K. Brázdil 2014).

The eastern fragment of the border between Poland and the Czech Republic, going through Cieszyn Silesia [Śląsk Cieszyński / Těšínsko], is the pre-war border between Poland and Czechoslovakia, established between 1918-1920 by the decision of the Conference of Ambassadors (M. Sobczyński 1986, pp. 13-14). Polish names on this section of the border are traditional names. The remaining part of the border has a much longer history. Its fundamental part (without eastern and western patches) is a former border between Austria and Prussia, which appeared as a result of overtaking almost all of Silesia (without the Duchy of Cieszyn and fragments of the Duchy of Nysa, Duchy of Krnov and Duchy of Opava) and Kłodzko Land, which previously belonged to Austria, by Prussia (K. Maleczyński 1963, pp. 479-494).
The western patch of the border is the former Czech-Saxon border ${ }^{2}$. After the disintegration of Austria-Hungary, it became a border between Czechoslovakia and Germany; however, its eastern fragment was changed: as a result of the Treaty of Versailles, the Hlučín Region [Hlučínsko], neighboring with Ostrava and Opava from the north, was incorporated into Czechoslovakia (R. Heck, M. Orzechowski 1969, p. 317). From 1945, it constituted the border between Czechoslovakia and Poland, and from 1993, the border between the Czech Republic and Poland. Since its establishment after World War I, this border, apart from some slight modifications ${ }^{3}$ and temporary changes during World War II and preceding years, has not been changed (fig. 1). Polish names along this section of the border were established (artificially to a large extent) after 1945. It should be noted that, due to the exchange of population on the Polish side after 1945 and to strict control of the border itself in the post-war period, development of the border linguistic and cultural space on this section, maintained on the section of Cieszyn Silesia, was rendered impossible (D. Chylińska, G. Kosmala 2010).

\section{Analyzed source material}

The analysis involved names used officially, understood here as names used on topographic maps and in databases of geographic names maintained by Polish and Czech geodetic and cartographic services. Various inflectional forms of names included in the aforementioned source materials, which occur in other publications or are used by the local population, were not analyzed. An emphasis was placed on the administrative approach to names; therefore, an analysis of forms established by relevant authorities involved in standardization of geographic names was conducted (E. Wolnicz-Pawłowska 2011).

2 It is a current fragment of the border between Poland and the Czech Republic in the area of Zgorzelec and Luban Counties; however; after the incorporation of Saxon Lausitz to Prussian Silesia in 1815 , as a result of the Congress of Vienna, the eastern half of this border became a fragment of the border between Austria and Prussia (S. Michalkiewicz 1970, p. 84).

${ }^{3}$ Last modification of its course took place in 1958 when more then $20 \mathrm{~km}^{2}$ in total changed nationality (J. Walczak 2014). 
Within the framework of selecting names of transboundary objects, names occurring on contemporary Polish and Czech topographic maps and in databases of geographic names available in national geoportals (as of mid-2013), as well as names from maps with officially used divisions into natural regions, were analyzed. The following cartographic materials were used:

1) materials contained in the Polish geoportal (geoportal.gov.pl):

- Mapa topograficzna Polski [Topographic map of Poland] 1:100,000,
- Regiony fizycznogeograficzne [Physico-geographical regions] $1: 1,500,000$ by Jerzy Kondracki and Andrzej Richling published in Atlas Rzeczypospolitej Polskiej [Atlas of the Republic of Poland],

- Vyšši geomorfologické jednotky České republiky [Major geomorphological units of the Czech Republic] 1:500,000.

From the analysis of the source materials, it can be concluded that on the border between Poland and the Czech Republic there are 360 named geographic objects ${ }^{4}$. They are: 123 watercourses, 139 summits, 22 passes, 35 mountain

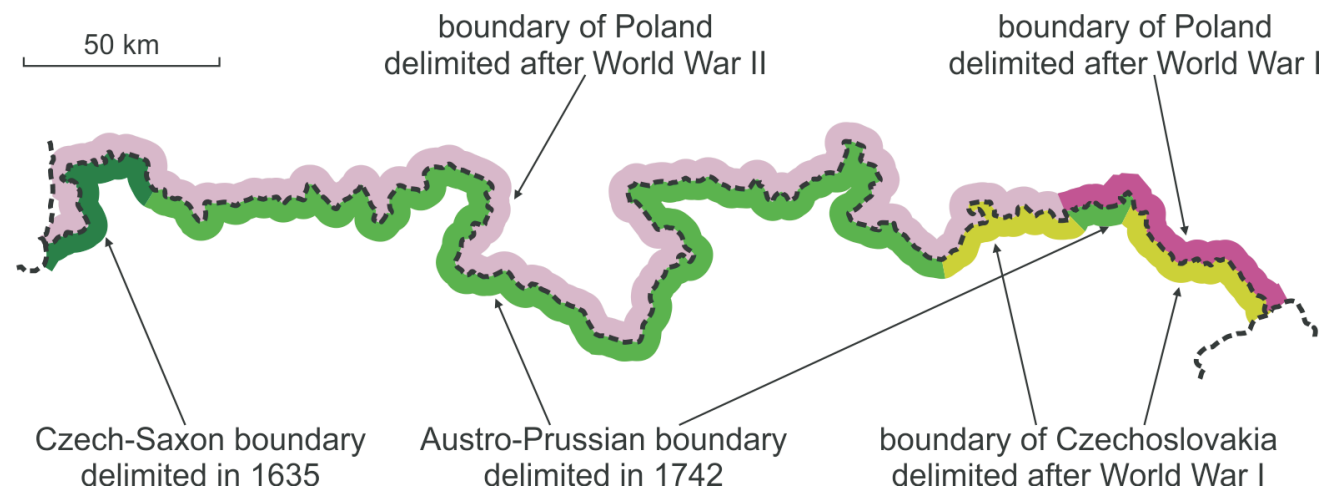

Fig. 1. The Polish-Czech boundary (elaborated by the author)

- Mapa topograficzna Polski [Topographic map of Poland] 1:50,000,

- Mapa topograficzna Polski [Topographic map of Poland] 1:25,000,

- Mapa topograficzna Polski [Topographic map of Poland] 1:10,000,

- Państwowy Rejestr Nazw Geograficznych [State Register of Geographical Names] (PRNG);

2) materials contained in the Czech geoportal (Geoportál ČÚZK, geoportal.cuzk.cz):

- Základní mapa České republiky [Base map of the Czech Republic] 1:50,000,

- Základní mapa České republiky [Base map of the Czech Republic] 1:25,000,

- Základní mapa České republiky [Base map of the Czech Republic] 1:10,000,

- Databáze geografických jmen České republiky [Database of Geographic Names of the Czech Republic] (Geonames);

3) maps with a division into physical geographical regions: ranges and ridges, 15 uplands and foothills, 7 valleys and basins, 3 lowlands, 3 rocks, 9 forests, 1 mountain meadow, and 3 trails.

As it can be observed, most of them are landform objects (orographic objects), such as: peaks, passes, mountain ranges and ridges, uplands, foothills, basins, lowlands, and rocks. Their names were included on the analyzed maps and databases of names in the case of 224 objects ( $62 \%$ of named objects). The second largest group includes water objects, which are represented by names of watercourses only, as on the border between Poland and the Czech Republic, there are no names of lakes, channels, swamps, waterfalls, etc. Hydronyms refer to $34 \%$ of named objects. Among trans-

\footnotetext{
${ }^{4}$ Due to the fact that calculating some objects was problematic (e.g. doubled names, clear mistakes in descriptions), the actual number of named objects can be slightly different than 360 .
} 


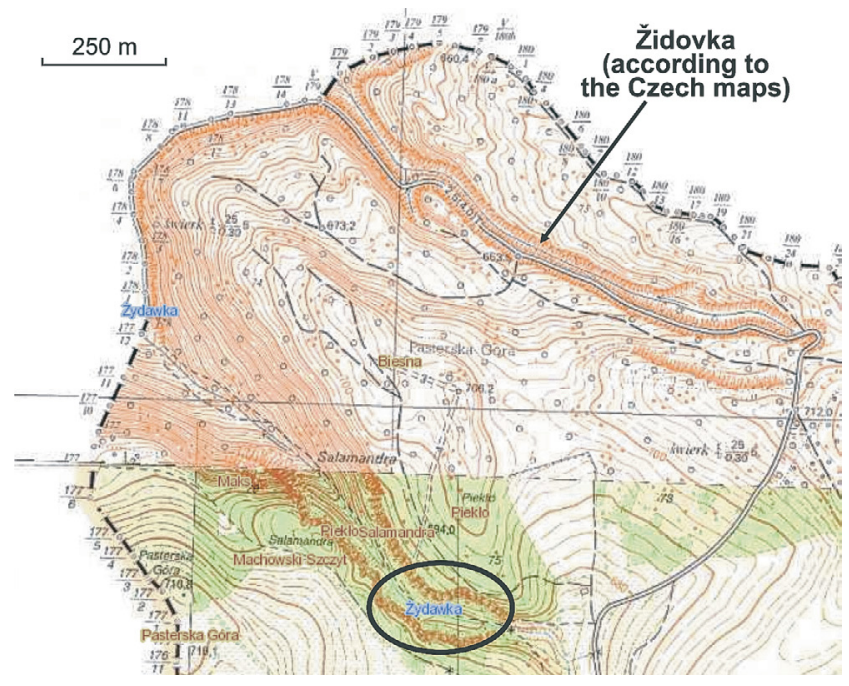

Fig. 2. The Żydawka on the Polish topographic map at the scale of 1:10,000 (with the names layer from the National Register of Geographical Names)

boundary names, there are no oikonyms, as the state border is always an administrative border of a given locality even though, historically, the locality may be located on both sides of the border ${ }^{5}$.

\section{Names of watercourses}

In the analyzed cartographic materials, there are 123 named watercourses on the border between Poland and the Czech Republic. Some of them only cross the border, while others are border watercourses in certain sections. In 77 cases $(63 \%)$, the watercourses have both Polish and Czech names, and the Polish name is consistent with the Czech name ${ }^{6}$ in 44 cases (57\% of watercourses with Polish and Czech name, which is $36 \%$ of all named watercourses, e.g. Nysa Łużycka - Lužická Nisa, Jawornicki Potok - Javornický potok, Boreczek - Boreček, Ścinawka - Stěnava, Graniczny Potok - Hranični potok), while the Polish name is different

\footnotetext{
${ }^{5}$ As in the case of Cieszyn, which is currently divided into two cities: Cieszyn in Poland and Český Těšín in the Czech Republic.

${ }^{6}$ Apart from identical names, such as Odra, names which constitute mutual translation and graphic or phonetic adaptation were considered consistent in both languages for the needs of this article.
}

than the Czech name in 33 cases $(27 \%$ of all named watercourses, e.g. Przepiórka - Jasný potok, Ziębówka - Saňský potok, Ostrożnica - Petřikovický potok, Czerwony Potok - Bilý potok, Maruszka - Františkovský potok). Eight watercourses have only a Polish name $(6 \%$ of named watercourses, e.g. Wolarz, Wilga, Bystrzyca Dusznicka, Lubrzanka), while 38 watercourses have only a Czech name $(31 \%$ of named watercourses, e.g. Černouský potok, Olšina, Zdaňovský potok, Heřmanický potok).

In ten cases, names and location of watercourses on Polish maps and in the register of geographic names do not correspond to Czech materials. For example, according to Czech maps the Stekelnice stream (near Kudowa-Zdrój town) is the left tributary of a stream called Židovka and both these streams have their sources in Poland. On Polish maps, the Żydawka stream (the name in accordance with the State Register of Geographical Names; described as Piekło on topographic maps) constitutes the Polish extension of a stream called Stekelnice in the Czech Republic, while Czech Židovka is the stream which does not have a name in Poland. In this case, Żydawka / Stekelnice is several times longer than the source section of Czech Židovka, and it should be considered the source of the stream. The accuracy of determining a watercourse on Polish maps con- 
firms its course determined on a hydrographic map $^{7}$ (fig. 2), while according to this map its name is Rejšenský potok (a name used on both the Czech and Polish side of the border [!]).

Another example is a stream called Tarnawka (according to maps from both countries, the second arm has no name) (fig. 4). The accuracy of determining the watercourse on Polish maps is confirmed by its course determined on the hydrographic map.
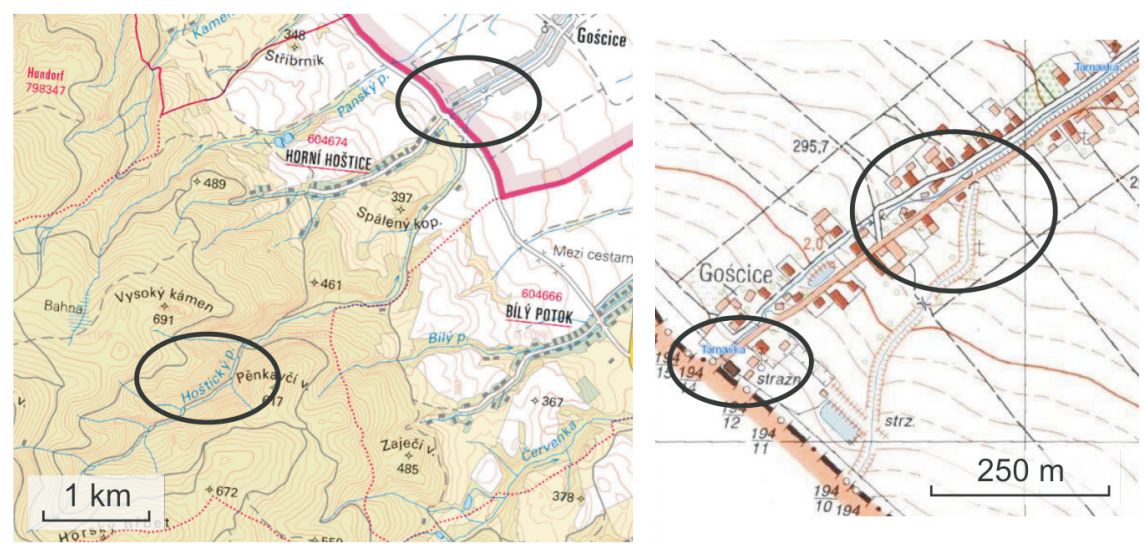

Fig. 3. The Hoštický potok on the Czech topographic map at the scale of 1:50,000 and the Tarnawka on the Polish topographic map at the scale of 1:10,000 (with the names layer from the National Register of Geographical Names)

on Polish maps, which enters Poland from the Czech Republic in Gościce (Paczków Commune). On the Czech side, the stream, going through the village of Horní Hoštice, has no name. Another stream flows into it just before the border on the Polish side; the stream does not have a name in Poland, while according to Czech maps it is Hoštický potok, significantly longer than Tarnawka, into which it is supposed to flow. Nonetheless, according to topographic maps and aerial photos, Tarnawka does not change its course and Hoštický potok, if it was to be considered to be the main one, would turn at a $90^{\circ}$ angle (fig. 3). The hydrographic map does not dispel doubts which of the streams should be considered to be the source.

Also watercourses such as Lipina / Šilheřovický potok (Racibórz County) might be listed here, as according to Polish and Czech maps they constitute different arms of the same river, separated from each other by approx. $150 \mathrm{~m}$

7 The course of streams has been verified with Rastrowa mapa podziału hydrograficznego Polski [Raster Hydrographical Map of Poland] 1:50,000.

\section{Names of summits}

On the border between Poland and the Czech Republic, there are 139 summits with names included on the analyzed maps and in databases of names. In most cases, summits are located on the border; however, in several cases the summit is located within several dozen or several hundred meters from the border, which goes along the hillside of the elevation.

In 80 cases ( $58 \%$ of named summits), the summits have both Polish and Czech names, while the Polish name is consistent with the Czech name in 38 cases $(48 \%$ of summits which have both Polish and Czech names, which is $27 \%$ of all named summits; e.g. Sokolnik - Sokolník, Mały Szyszak - Malý Šišák, Śnieżka - Sněžka, Pańska Góra - Panský kopec, Mały Śnieżnik - Malý Sněžník), while in 42 cases (30\% of named summits), the Polish name is different than the Czech name, e.g. Granicznik - Strnči vrch, Łabski Szczyt - Violík, Orlica - Vrchmezí, Trójmorski Wierch - Klepáč, Góra Wężowa - Hraniční kopec. It is worth noting that all cases where the Polish name is 


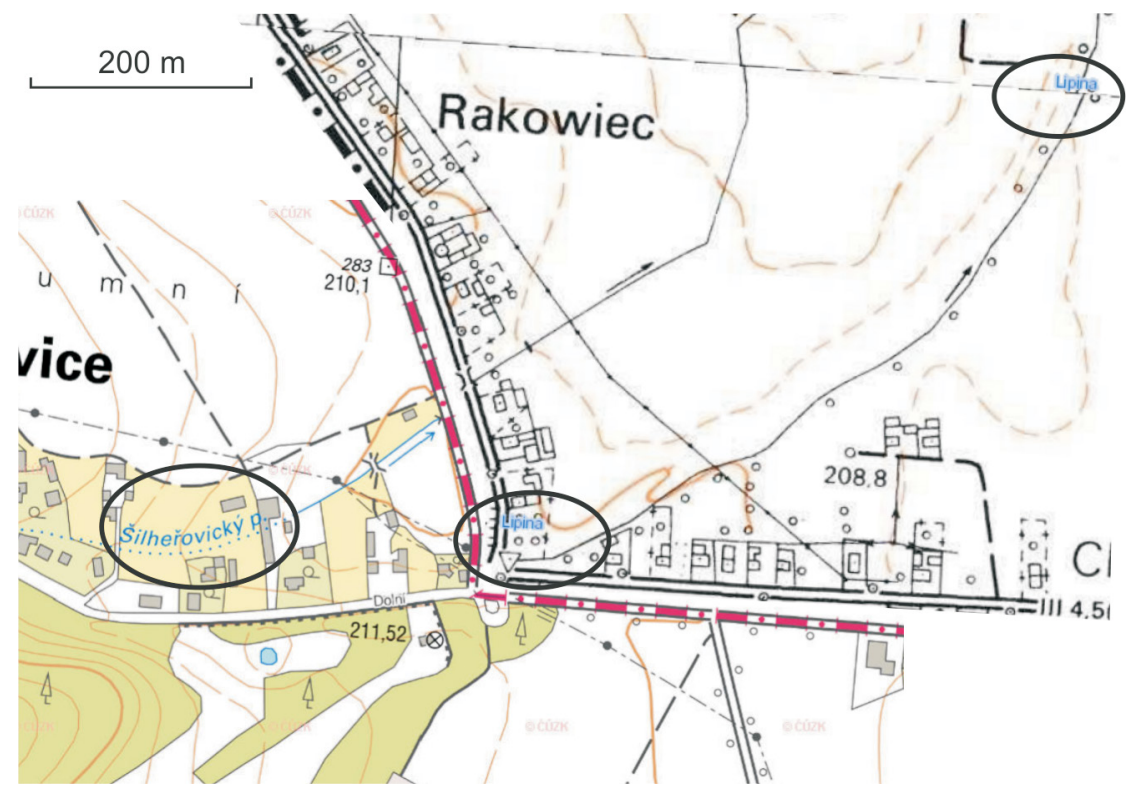

Fig. 4. Watercourse of the Lipina / Šilheřovický potok on the Polish topographic map (with the names layer from the National Register of Geographical Names) and the Czech topographic map, both at the scale of 1: 10,000

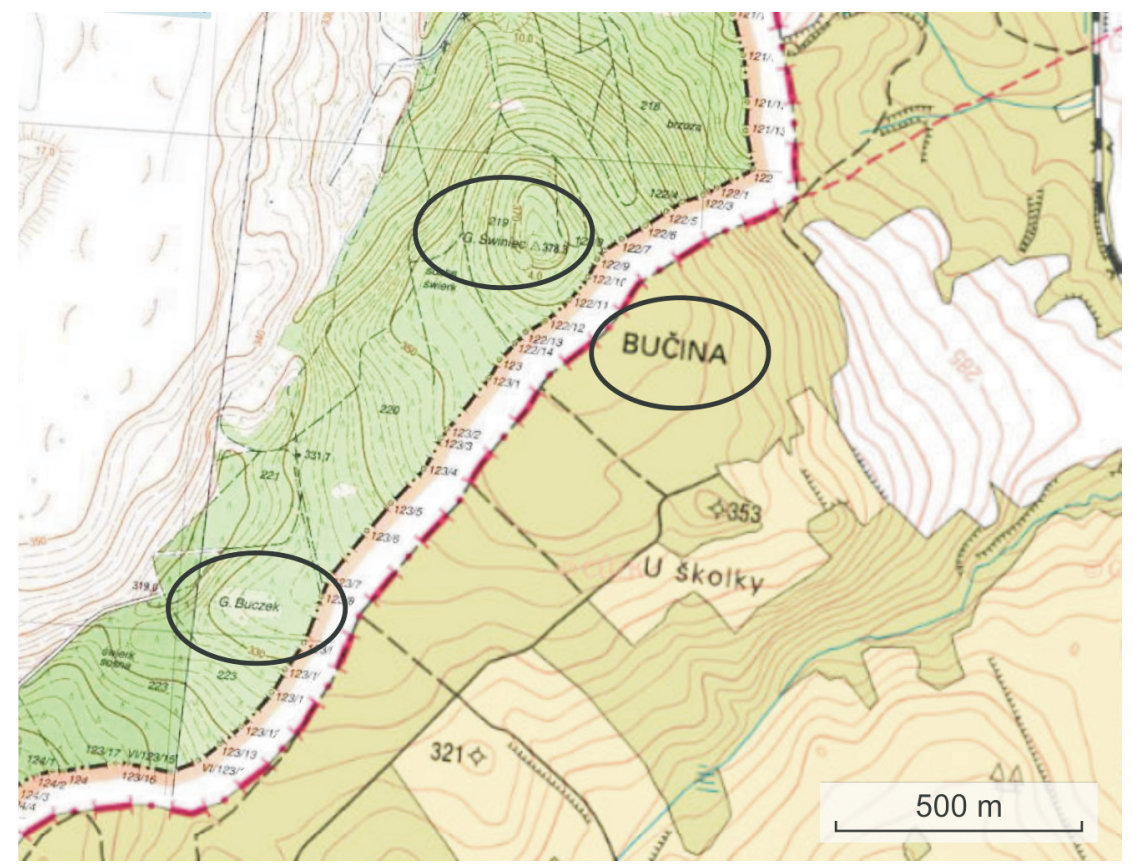

Fig. 5. The location of Świniec / Bučina and Buczek summits on the Polish and the Czech topographic maps, both at the scale of 1:10,000 
not consistent with the Czech name are located in the western part of the border (post-war), and none of them are on the pre-war border between Poland and Czechoslovakia on Cieszyn Silesia. 38 summits have Polish names only $(27 \%$ of named summits, e.g. Łysocina, Jaworowa, Płoszczyniec, Jawornik Mały), while 21 summits have only Czech names (15\% of named summits, e.g. Mravenči vrch, Ptačí vrch, Šerlich, Vlčí důl).

In some cases, there is a shift of Czech names as compared to Polish names, a name applied in one country corresponds to a name applied in another country for a different, closely situated summit (it takes place only on the post-war section of the border). And, therefore, an elevation called Świniec in Polish (Pogórze Izerskie / Frýdlantská pahorkatina) has the Czech name Bučina, while the Polish name Buczek refers to the summit located approx. $1 \mathrm{~km}$ to the south (fig. 5).

Another example of such a shift of a Polish name as compared to a Czech name involves a well-known summit in Karkonosze Mountains, Wielki Szyszak, which has the Czech name of Vysoké Kolo. At the same time, the Czech name Velký Šišák belongs to the neighboring summit located only $800 \mathrm{~m}$ to the east, called Śmielec in Poland (fig. 6). Most likely, when Polish names were established after World War II, some summits were mistakenly named.

Also in Karkonosze Mountains, there is another shift of names. There are two groups of rocks named Mužské kameny ['Male Rocks'] and Divči kameny ['Female Rocks'] in the Czech Republic, which in Poland are called Czeskie Kamienie ['Czech Rocks'] and Śląskie Kamienie ['Silesian Rocks']. However, approximately $400 \mathrm{~m}$ to the northeast from Śląskie Kamienie, there is an another group of rocks called in Polish Skały Panieńskie Małe ['Little Female Rocks'], completely located in Poland. The Polish name was accepted despite the fact that there is not other group of rocks called in Polish Skały Panieńskie (fig. 7).

Another example of a shift of names are two neighboring border summits in the Bystrzyckie Mountains, which are referred to as Kamieńczyk and Graniczny Wierch ['Border Peak'] in Poland, even though in the Czech Republic they are called Přední Hraniční vrch ['Front Border Peak'] and Zadní Hraniční vrch ['Rear Border Peak'] (fig. 8).

Another interesting example is located in the Izerskie Mountains. There are two summits of a similar height $(1,124 \mathrm{~m}$ and $1,123 \mathrm{~m}$ above

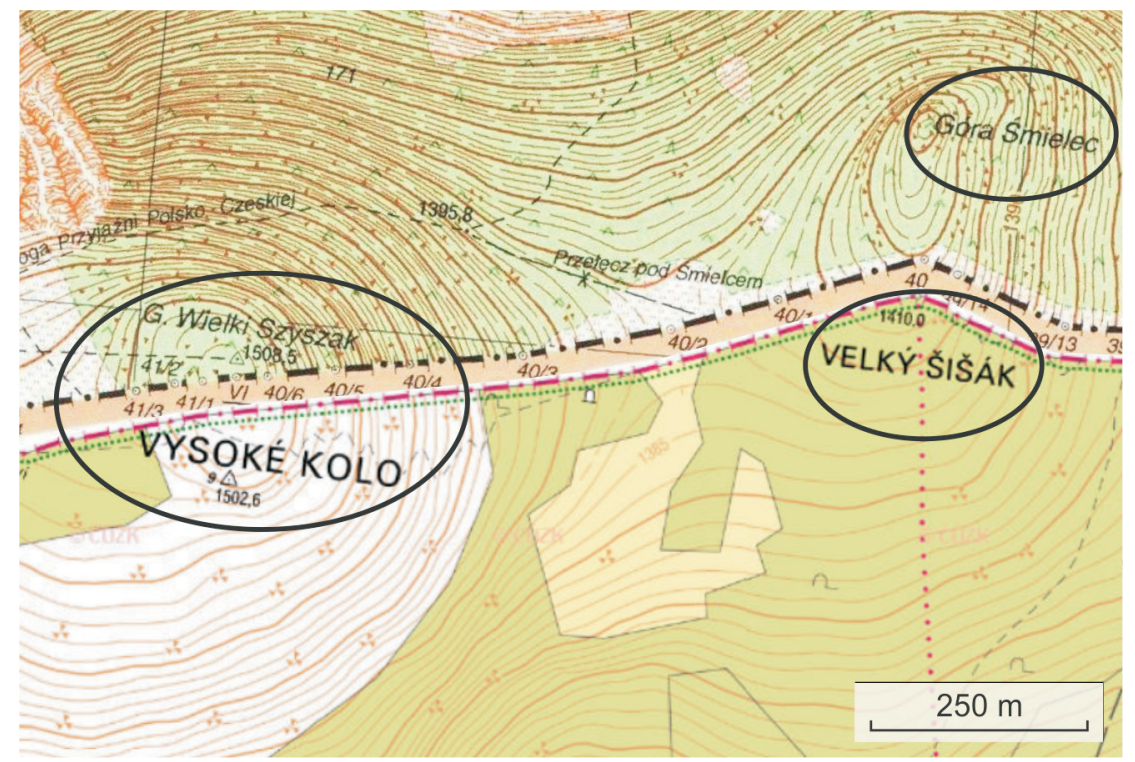

Fig. 6. Wielki Szyszak / Vysoké Kolo and Śmielec / Velký Šišák summits on the Polish and the Czech topographic maps at the scale of 1:10,000 


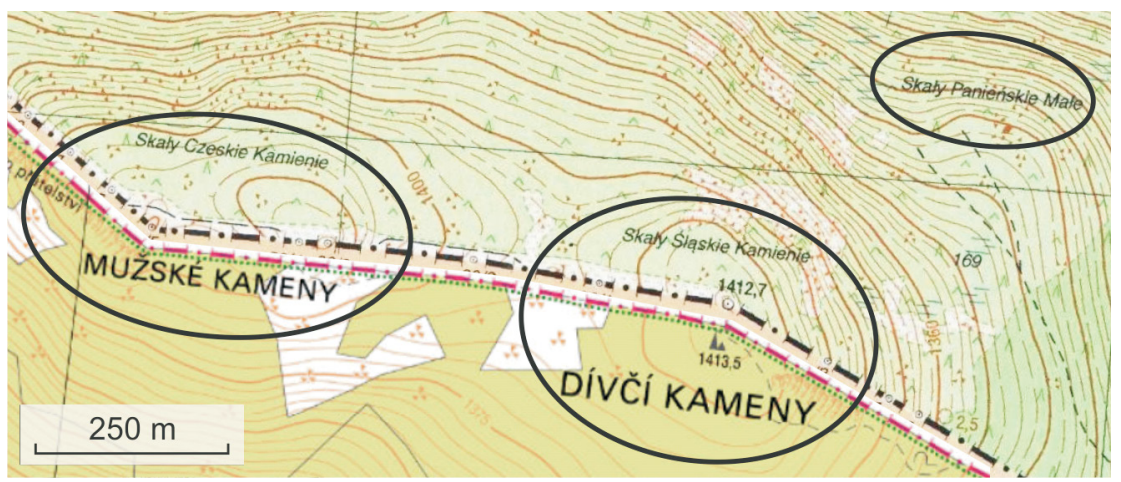

Fig. 7. Mužské kameny / Czeskie Kamienie, Divči kameny / Śląskie Kamienie, and Skały Panieńskie Małe on the Polish and the Czech topographic maps, both at the scale of 1:10,000

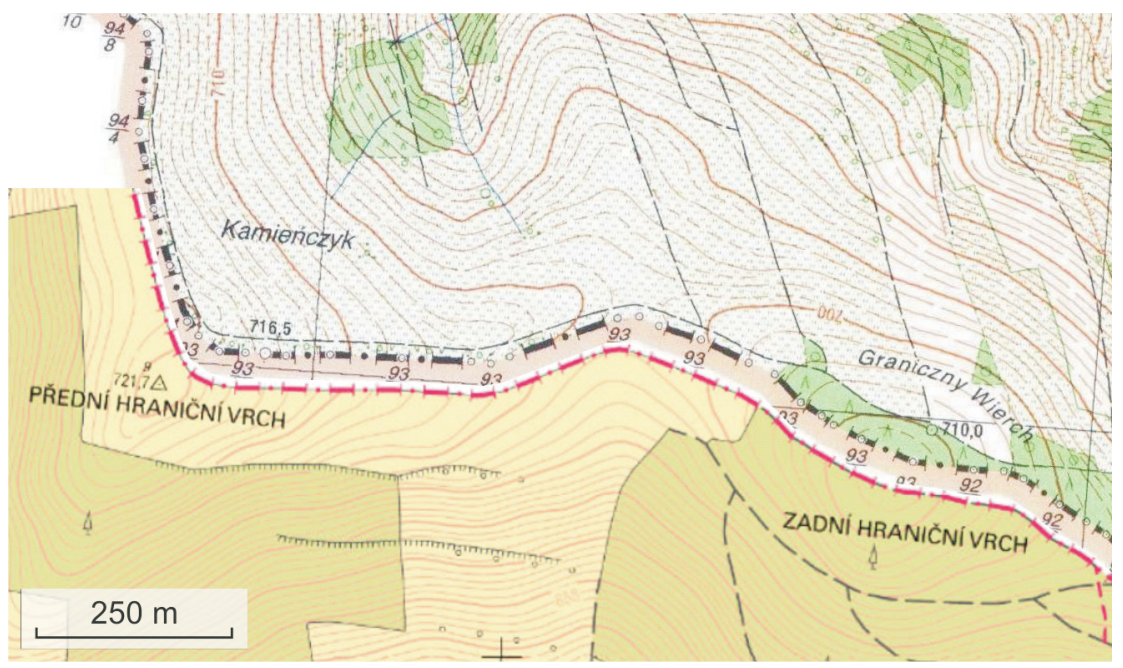

Fig. 8. Kamieńczyk / Přední Hranični vrch and Graniczny Wierch / Zadní Hraniční vrch on the Polish and the Czech topographic maps, both at the scale of 1:10,000

sea level) located approximately $500 \mathrm{~m}$ from each other - one in the Czech Republic (the higher of the two) and one in Poland. Both summits actually have the same name - Smrk and Smrek respectively (fig. 9). An identical name of two neighboring elevations can lead to misunderstandings - these kinds of names are normally differentiated with appropriate adjectives, e.g. big and small, front and rear, western and eastern, but in this case it was not done.

An analogical situation occurs in the Złote
Mountains / Rychlebské Mountains. Moreover, it concerns summits with names identical as in the previous example. There are two summits approximately $900 \mathrm{~m}$ apart - one in the Czech Republic (it is the main summit located close to the border $1,127 \mathrm{~m}$ above sea level) and one in Poland (1,107 $\mathrm{m}$ above sea level), called Smrk and Smrek (fig. 10). Also in this case, it would be a good idea to differentiate the names of both elevations by adding an adjective indicating their location or some other characteristic of the summits. 


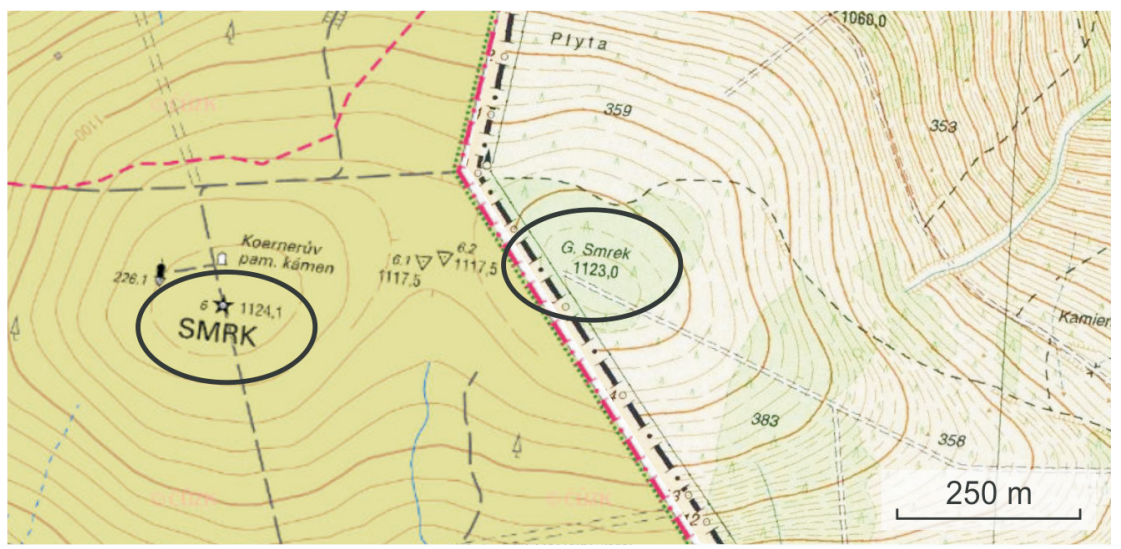

Fig. 9. Smrk and Smrek summits on the Polish and the Czech topographic maps, both at the scale of 1:10,000

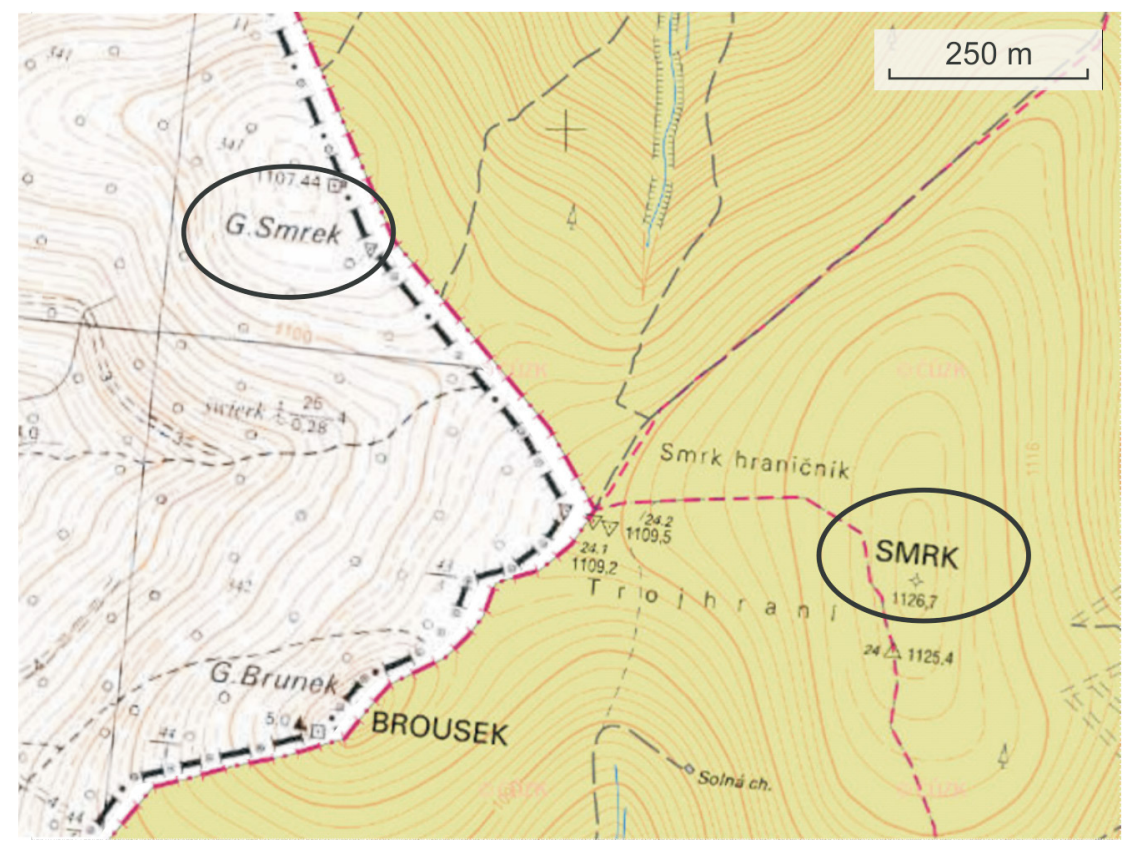

Fig. 10. Smrk and Smrek summits on the Polish and the Czech topographic maps, both at the scale of 1:10,000

\section{Names of small mountains, ridges and slopes not being mesoregions}

In the analyzed cartographic materials, 13 objects of this type existing on the border between Poland and the Czech Republic were named. In 7 cases (54\% of named objects of this kind), the objects have both Polish and
Czech names, of which in 3 cases the Polish name corresponds to the Czech one (Bobrowy Stok - Boberská strán̆, Góry Krucze - Vraní hory, Mieroszowskie Ściany-Mirošovské stěny), and in 4 cases, the names do not correspond with each other (Góry Suche - Javoři hory, Czarny Grzbiet - Obrí hřeben, Kowarski Grzbiet - Lesni hřeben). In 3 cases (27\%), the 
objects only have a Polish name - Zawory, Jaskóła, Graniczne Zbocze; and also in 3 cases, they only have a Czech name - Hranični hřbet (in the Broumovská vrchovina), Střecha, Hranični hřbet (in the Massif of Śnieżnik).

\section{Names of passes}

On the border between Poland and the Czech Republic, there are 22 named passes. In 6 cases ( $27 \%$ of named passes), the passes have both Polish and Czech names. The Polish name is consistent with the Czech name only in the case of one pass: Beskidek-Beskydské sedlo (it is the only named transboundary pass in the region of Cieszyn Silesia). In 5 other cases, Polish names are different than Czech names: Przełęcz Szklarska - Novosvětský průsmyk, Karkonoska Przełęcz - Slezské sedlo, Przełęcz Lubawska - Královecký průsmyk, Przełęcz Międzyleska - Mladkovské sedlo, Przełęcz Płoszczyna - Kladské sedlo.

In the case of the remaining named passes (16 cases, $73 \%$ ), they all have only Polish names: Mokra Przełęcz, Pod Śmielcem, Czarna Przełęcz, Dołek, Pod Śnieżką, Sowia Przełęcz, Przełęcz [!] Okraj, Przełęcz Krzeszowska,
Przełęcz Chełmska, Trzy Koguty, Pod Czarnochem, Działowe Siodło, Przełęcz Gierałtowska, Przełęcz Karpowska, Lądecka Przełęcz, Różaniec. There are no passes with only Czech names. On Czech maps, the lack of names of numerous passes is striking - of all named border passes up to three fourths do not have Czech names, including important passes, such as Okraj, which is a significant border crossing.

Among named passes, three raise doubts. In the Karkonosze Mountains, there is Przełęcz Szklarska with the Czech name Novosvětský průsmyk; however, the appropriate pass is not located on the border, but approximately $1 \mathrm{~km}$ from the border in Jakuszyce in Poland. Contrary to the entries on Czech maps, it is not a transboundary object (fig. 11). In 1958, a change of the border was introduced; previously the border run somewhat further to the north, closer to the actual pass (Topografická mapa... 1956). However, also before the change of the border, the pass was not marked on Czech maps in its actual location.

Przełęcz Krzeszowska (in Lubawka Commune) is listed in the State Register of Geographical Names. However, in the location, there

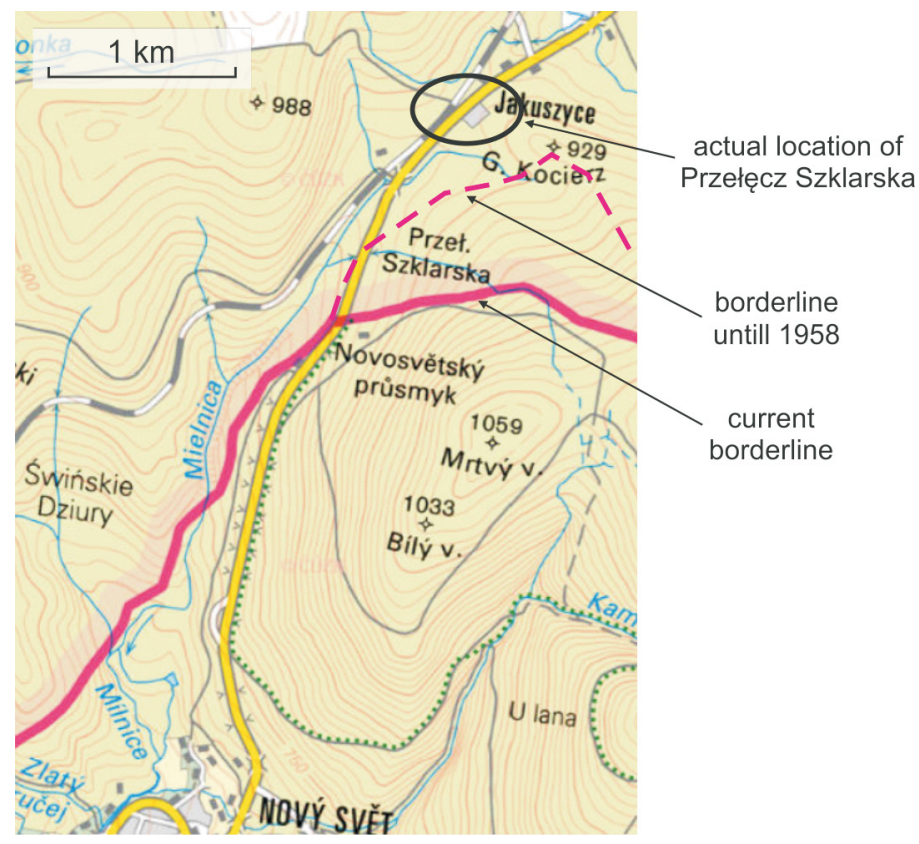

Fig. 11. Novosvětský průsmyk / Przełęcz Szklarska on the Czech topographic map at the scale of 1:50,000 


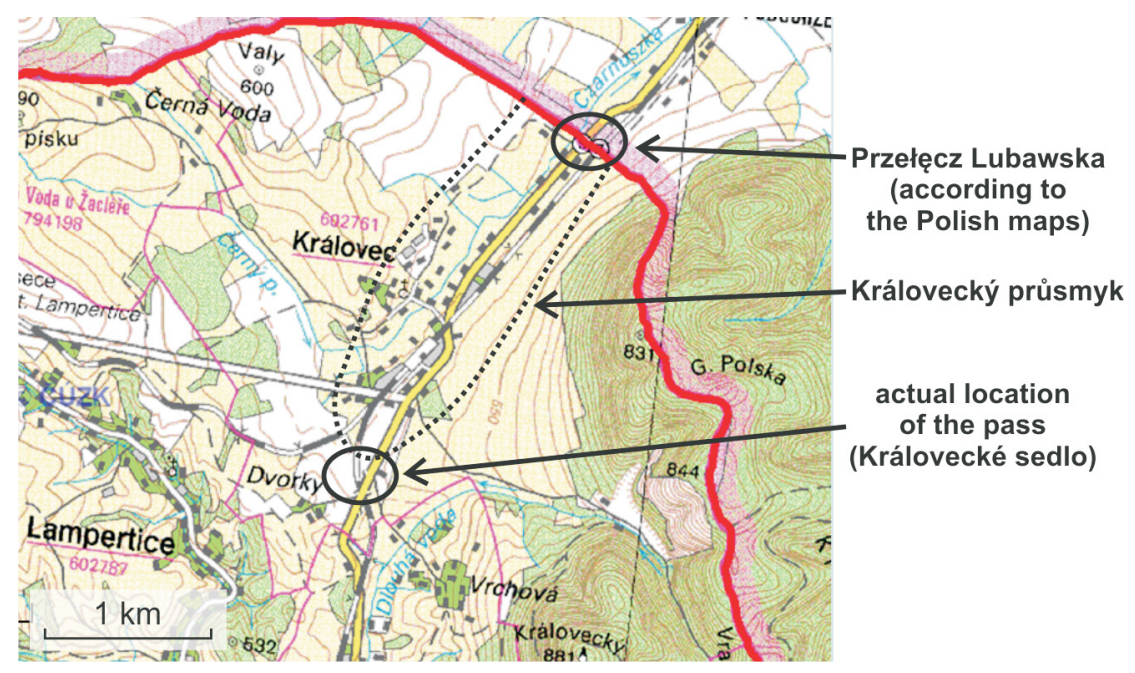

Fig. 12. The location of Przełęcz Lubawska, Královecký průsmyk, and Královecké sedlo on the Czech topographic map at the scale of 1:50,000

is no pass at all - it is a section of a valley, and the alleged pass would be located in the place of a border stream.

A pass marked on Polish maps as Przełęcz Lubawska is a place of a former border crossing. The pass is marked as located on the border not only on Polish topographic maps or in the State Register of Geographical Names, but also in the list of Geographical Names of the Republic of Poland from 1991, and on numerous Polish tourist maps. However, the state border runs across the valley of the Czarnuszka stream (called also as Bober or Czarna Woda in Poland and as Černý potok in the Czech Republic), and on the border, in the supposed location of the pass, there is a border stream (it has no Polish name, and the Czech name is Královecký potok or Hranični potok), and there is obviously no pass. The actual pass is not on the border, but more than $2.5 \mathrm{~km}$ from the border in the Czech Republic, opposite the Czech town of Královec, and it is called Královecké sedlo. The object is located in the physico-geographical mesoregion, which in Poland is called Brama Lubawska.

All the confusion most likely originates from the fact that there are two objects - a pass and a geomorphological gate, which in Poland are named Przełęcz Lubawska and Brama Lubawska respectively. According to contemporary Czech topographic maps and the register of geographic names Geonames, the actual pass is called Královecké sedlo, while the area located in the north from the pass and extending to the border with Poland (which is a southern part of Polish Brama Lubawska) is called Královecký průsmyk. Occasionally we can come across the name of Libavské sedlo (Libovské sedlo), treated either asthe variant for the name of Královecké sedlo or for an object located on the border (fig. 12).

Perhaps, the fact that in Czech both the pass and the gate are called a pass ${ }^{8}$ explains where the Polish name Przełęcz Lubawska comes from. The Polish name of Przełęcz Lubawska was officially established in 1949 (Rozporządzenie Ministra... 1949). It was then assumed that an equivalent of the German name Königshaner Pass is the Polish name Przełęcz Lubawska9. What is important, only

\footnotetext{
8 The Czech term 'průsmyk' means a 'pass' ('przełęcz' in Polish), while the term 'sedlo' in Czech corresponds rather to the term 'pass' and not 'saddle' ('siodło' in Polish), as it would result from the literal translation, e.g. Karkonoska Przełęcz in Czech is Slezské sedlo, Przełęcz Międzyleska - Mladkovské sedlo, etc.

${ }^{9}$ The name Königshaner Pass (also used as Königshainer Pass) originates from the German name Königshan of the town of Královec. The name (or any other name of the pass) was not considered on the pre-war topographic German maps, scale 1:25,000 (Topographische Karte... 1943) and 1:100,000 (Karte des... 1932).
} 
the name of the object, and not its type, was provided in this regulation. Only in the following years did it start to be determined to be a pass. Probably, this Polish name established in 1949 (as well as the pre-war name) referred to the entire today's Brama Lubawska, and not to the pass. The word 'pass' in this name should be, therefore, considered to be a false generic term.

\section{Names of other small objects}

On the border between Poland and the Czech Republic, there are 19 named objects of this kind: 1 valley, 1 bassin, 1 plateau, 3 rocks, 1 mountain meadow, 9 forests and 3 trails.

In 7 cases ( $37 \%$ of named objects), the objects have both Polish and Czech names (of which in 5 cases the Polish name corresponds to the Czech name): U Trzech Granic - Trojhrani [bassin], Równia pod Śnieżką - Úpská rašelina [plateau], Twarożnik - Tvarožník [rock], Trzy Świnki - Svinské kameny [rocks], Pod Kamiennikiem - Lubošská planina [mountain meadow], Graniczny Las - Hraniční les [forest], Droga Przyjaźni Polsko-Czeskiej - cesta Českopolského prátelství [trail].

10 objects have only Polish names (53\%): Dolina Beczkowskiego Potoku [valley], Bogatyńskie Lasy [forests], Miedziański Las [forest], Grabiszycki Las, Miloszowski Las, Dobrzyca [forest], Świeciański Las, Czerniawski Las, Ścieżka nad Reglami [trail], Droga Jubileuszowa [trail]; while 2 objects have only Czech names (10\% of named objects): Bor [rock], Hájek [forest].

\section{Names of physico-geographical regions}

In neighboring countries, the division of physico-geographical regions is important as well, especially mesoregions and macroregions. On the border between Poland and the Czech Republic, there are physico-geographical regions determined and approved both in Poland and the Czech Republic.

Names of higher-order units, such as provinces and sub-provinces are mostly used in a narrow scientific community, e.g. Niziny Środkowopolskie [Central Polish Lowlands], Karpaty Zachodnie z Podkarpaciem Zachodnim i Północnym [The Western Carpathians with Western and Northern Subcarpathia], but not always because names such as Sudety [sub-province] (Czech: Krkonošsko-jesenická subprovincie), Karpaty [the Carpathians; province] (Czech: Karpaty), Masyw Czeski [Bohemian Massif; province] (Czech: Česká vysočina) are commonly known and used. In the case of physico-geographical provinces and sub-provinces, 11 of them are objects, which are partially located on both sides of the border. Their names are mostly consistent in both languages (previously mentioned the name Sudety constitutes an exception); the reach of the units themselves is consistent, as well.

In the Czech Republic, 8 macroregions, which are partially located in Poland, were determined. The Polish division, despite the fact that it is generally less precise (units in the Czech Republic were determined on a 1:500,000 scale map, while in Poland the scale was three time smaller - 1:1,500,000), contains 10 macroregions located partially in the Czech Republic (fig. 13) ${ }^{10}$.

Some of the units have a corresponding reach:

- Sudety Środkowe - Orlická oblast (according to the Czech division the region extends much further to the south; however, they have a corresponding reach in the border area),

- Sudety Wschodnie - Jesenická oblast,

- Przedgórze Sudeckie - Krkonošsko-jesenické podhůrí,

- Nizina Śląska - Slezská nížina (according to the Polish division, it includes a slightly larger part of the Osoblažsko region (Slezská Haná), the so called Osoblaha hook - one of Moravian enclaves in Silesia),

- Pogórze Zachodniobeskidzkie - Západobeskydské podhůrí.

On the border between Poland and the Czech Republic, also Beskidy Zachodnie (Polish) / Západní Beskydy (Czech) have a corresponding reach. However, it is only the western section of the object. According to the Polish division, the region is significantly larger and includes three macroregions divided according to the Slovak division (former Czechoslovak one) and, consequently, in the Czech division: Západné Beskydy, Stredné Beskydy i Východné Beskydy (Geomorfologické jednotky... 1980).

\footnotetext{
10 On Polish maps, the reach of the regions was presented also beyond the borders, while on Czech maps their reach was presented only in the Czech territory.
} 
Two other macroregions are determined differently in both countries:

- Czech Severní Vněkarpatské sníženiny corresponds to three macroregions determined in Poland: Kotlina Ostrawska (in the Czech division it is a mesoregion and not a macroregion), a part of Wyżyna Śląska, and a part of Kotlina Oświęcimska,
- Czech Krkonošská oblast corresponds to three macroregions determined in Poland: Pogórze Zachodniosudeckie, Sudety Zachodnie and Pogórze Karkonosko-Jesenickie [!] which is fully located in the Czech Republic (in the Czech division it is the mesoregion named Krkonošské podhůrí, while Krkonošsko-jesenické podhưríi corresponds to Przedgórze Sudeckie).

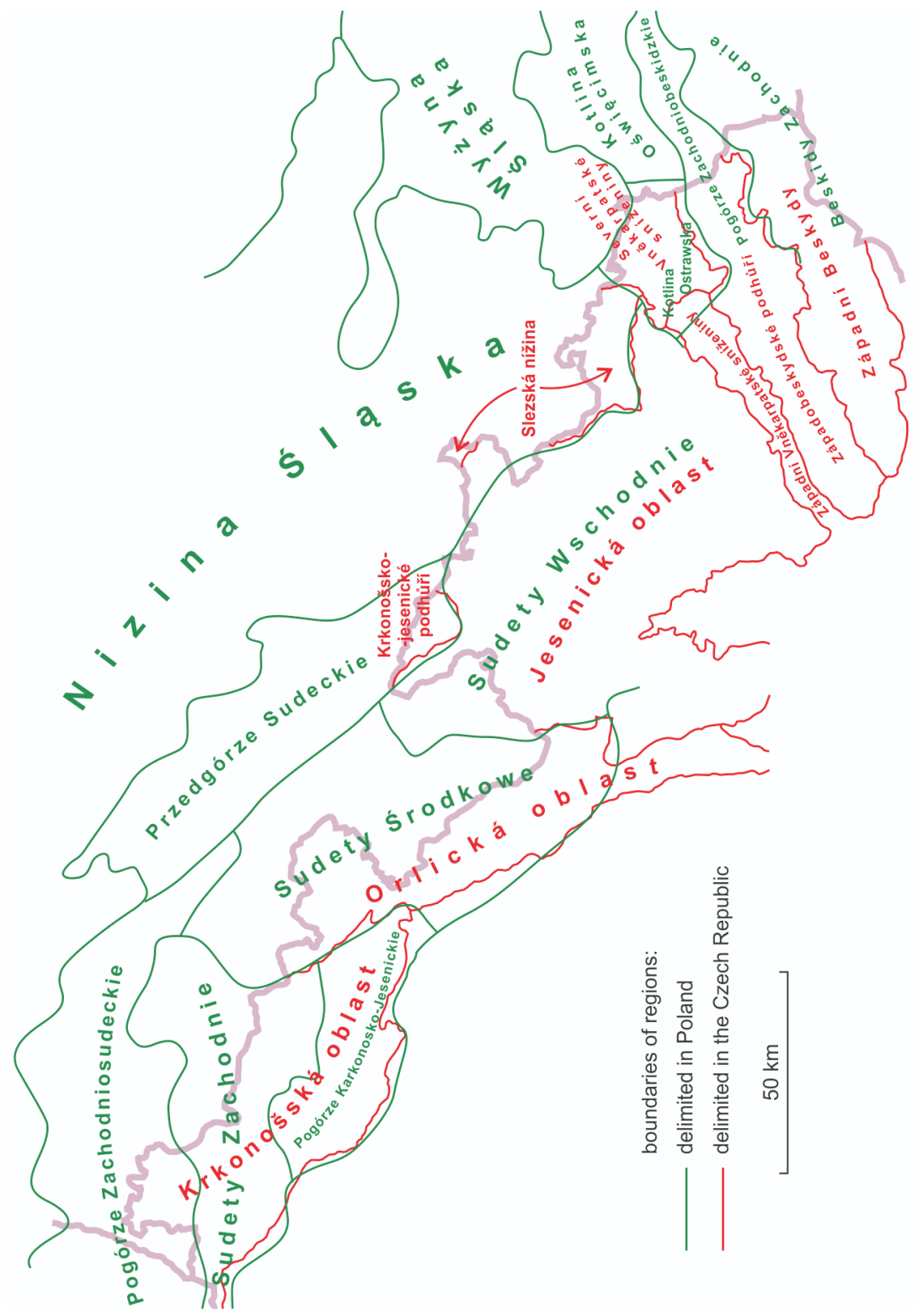

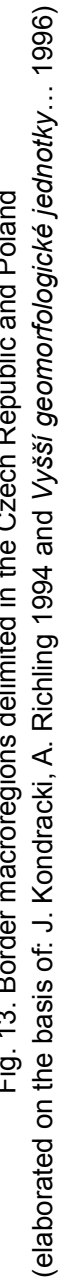


Mesoregions are lower-order units in physico-geographical regionalization. In the Czech division, 20 mesoregions partially located in Poland were determined, whereas in the Polish division, 22 such mesoregions were determined (fig. 14).

Nine of these mesoregions have a more or less corresponding reach. They are:

- Obniżenie Żytawsko-Zgorzeleckie - Žitavská pánev (the region has slightly wider borders according to the Polish division than according to the Czech division),

- Pogórze Izerskie - Frýdlantská pahorkatina,

- Góry Izerskie - Jizerské hory,

- Karkonosze - Krkonoše.

- Kotlina Kłodzka - Kladská kotlina,

- Masyw Śnieżnika - Králický Sněžník,

- Góry Złote - Rychlebské hory,

- Góry Opawskie - Zlatohorská vrchovina (the region has a slightly smaller reach in the east according to the Polish division than according to the Czech division),

- Płaskowyż Głubczycki - Opavská pahorkatina (the region has a slightly smaller reach in the west according to the Czech division than according to the Polish division).

In the remaining cases, the discrepancies vary as to their degree. The largest differences in the division into mesoregions can be observed west of Kotlina Kłodzka [Kłodzko Basin] - here the Czech and Polish divisions are significantly different: Góry Bystrzyckie and a part of Góry Orlickie in the Polish division correspond to Orlické hory in the Czech division. The remaining part of Góry Orlickie as well as whole Pogórze Orlickie correspond to Podorlická pahorkatina in the Czech division. Four mesoregions determined in Poland, named Góry Stołowe, Obniżenie Ścinawki, Góry Kamienne, Brama Lubawska, correspond to one Czech mesoregion - Broumovská vrchovina. Moreover, Przedgórze Paczkowskie (east of Kłodzko Basin) determined in the Polish division corresponds to two mesoregions in the Czech Republic: Žulovská pahorkatina and Vidnavská nižina. The Czech region of Ostravská pánev (eastern part of the border) corresponds to two mesoregions in Poland: Kotlina Ostrawska and Wysoczyzna Kończycka. The Czech division of the western part of Beskid Śląski mountains is more precise - three Czech mesoregions, named Slezské Beskydy, Jablunkovské mezihorí, and Jablunkovská brázda (part) - correspond to one Polish mesoregion of Beskid Śląski.

\section{Summary}

From the analysis of toponyms conducted for 360 geographic objects located on the border between Poland and the Czech Republic and included in Polish and Czech official cartographic materials, it can be concluded that 212 of these objects (59\%) have both Polish and Czech names, while $148(41 \%)$ have names only in one language: 67 objects (18\%) have only Czech names, and 81 (23\%) have only Polish names. Among the objects with both Polish and Czech names, the Polish names are consistent with the Czech names in 113 cases (31\% of all named objects), while the Polish names are different than the Czech names in 99 cases $(28 \%)$.

Having analyzed the names used for transboundary objects located on the border between Poland and the Czech Republic, it can be stated that Polish and Czech names of these objects were established mostly without taking into consideration the names used in the neighboring country. Only for $31 \%$ of the objects, Polish and Czech names consistent with one another were established. It especially concerns Polish names established after 1945 on new post-war borders (fig. 1). In particular, it is clearly visible in the case of the names of peaks and passes, where on the pre-war border within Cieszyn Silesia there are no discrepancies between the Polish and Czech names being used. Numerous inconsistencies occur in the case of names of the objects only on the section of the border established after World War II.

It is also worth paying attention to international arrangements regarding names of transboundary objects. The resolution No. 25 of the Second United Nations Conference on the Standardization of Geographical Names (1972, with amendments passed by the resolution No. 20 of the Third Conference, 1977) recommends "that countries sharing a given geographical feature under different names should endeavour, as far as possible, to reach agreement on fixing a single name for the feature concerned", furthermore the resolution No. 25 of the Fifth Conference (1982) recommends "that those national geographical names authorities that have not yet done so establish with neighbouring authorities joint or interrelated programmes for the collection and treatment of names of features extending across their 


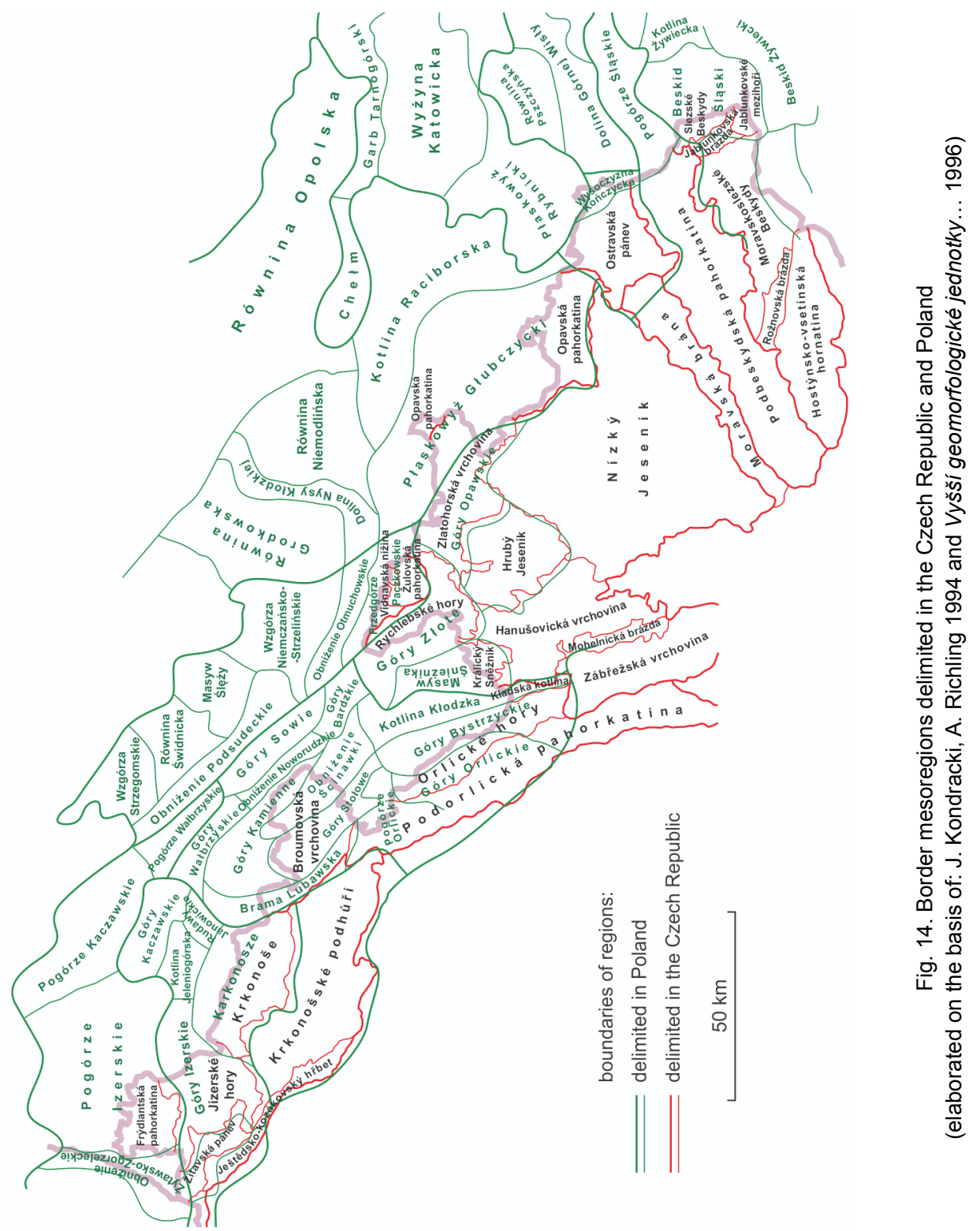

common borders" (Resolutions adopted... 2014). Considering this, establishing transboundary names of geographic objects, the names (and reach) should be verified with the names used on the other side of the border. Consultations on this subject should be conducted in an operational mode by the Polish Commission on Names of Localities and Physiographic Objects (Komisja Nazw Miejscowości i Obiektów
Fizjograficznych) and the Czech Commission on Geographical Names of the Czech Office for Surveying, Mapping and Cadastre (Názvoslovná komise Českého úřadu zeměměřického a katastrálního).

The Commission on Names of Localities and Physiographic Objects currently works on the official list of names of physiographic objects. Therefore, it is the right moment to cor- 
rect the Polish names of the objects located on the border between Poland and the Czech

\section{Literature}

Brázdil K., 2014, K výšce Sněžky, Praha: Český úřad zeměměřický a katastrální. http://www.cuzk. cz/Aktuality-resort/20140225/Snezka.aspx (access: 30.01.2015).

Chylińska D., Kosmala G., 2010, Analiza zmian nazw lokalnych Chełmska Śląskiego i Racławiczek w XX wieku jako przykład geograficznych badań przestrzeni toponimicznej Śląska, „Polski Przegląd Kartograficzny" T. 42, nr 1, pp. 30-39.

Heck R., Orzechowski M., 1969, Historia Czechosłowacji, Wrocław: Zakład Narodowy imienia Ossolińskich.

Kadmon N., 2014, Słownik terminów używanych przy standaryzacji nazw geograficznych, Warszawa: Główny Urząd Geodezji i Kartografii (online: http:// ksng.gugik.gov.pl/pliki/glossary_of_terms_PL.pdf).

Maleczyński K. ed. 1963, Historia Śląska, t. 1 do roku 1763, cz. 3 od końca XVI w. do r. 1763, Wrocław: Zakład Narodowy imienia Ossolińskich.

Mały Rocznik Statystyczny Polski 2014, Warszawa: Główny Urząd Statystyczny (online: http://stat. gov.pl/download/gfx/portalinformacyjny/pl/defaultaktualnosci/5515/1/15/1/maly_rocznik_statystyczny_2014.pdf).

Michalkiewicz S. ed. 1970, Historia Śląska, t. 2 1763-1850, cz. 2 1807-1850, Wrocław: Zakład Narodowy imienia Ossolińskich.

Nazwy geograficzne Rzeczypospolitej Polskiej, 1991, Warszawa: Główny Geodeta Kraju, Komisja Ustalania Nazw Miejscowości i Obiektów Fizjograficznych, Państwowe Przedsiębiorstwo Wydawnictw Kartograficznych im. Eugeniusza Romera.

Resolutions adopted at the Ten United Nations Conferences on the Standardization of Geographical Names, 2014, Ottawa: Natural Resources Canada, http://unstats.un.org/unsd/geoinfo/UNGEGN/docs/ RES_UN_E\%20updated_1-10\%20CONF.pdf (access: 30.01 .2015 ).

Rozporządzenie Ministra Administracji Publicznej z dnia 28 maja 1949 r. o przywróceniu i ustaleniu nazw miejscowości, „Monitor Polski” 1949, nr 44, item 592 (online: http://www.monitorpolski.gov.pl/ mp/1949/592/M1949044059201.pdf).
Republic which were incorrectly named or determined.

Sobczyński M., 1986, Kształtowanie się karpackich granic Polski (w w. $X-X X$ ), Łódź: Zarząd Wojewódzki PTTK Regionalna Pracownia Krajoznawcza (online: http://geopol.geo.uni.lodz.pl/wp-content/ uploads/2010/12/granice karpackie.pdf).

Walczak J., 2014, Stosunki polsko-czeskie, „Ziemia Kłodzka" nr 245, pp. 4-8 (online: http://www.ziemia. klodzka.com/pdf/241.pdf).

Wolnicz-Pawłowska E., 2011, Naukowiec, ekspert, urzędnik - funkcje i role językoznawcy w procesie standaryzacji nazw geograficznych, In: Biolik M., Duma J. ed. Chrematonimia jako fenomen współczesności, Olsztyn: Wydawnictwo Uniwersytetu Warmińsko-Mazurskiego, pp. 519-532.

\section{Maps}

Geomorfologické jednotky, 1:500 000, 1980, [In]: Atlas Slovenskej socialistickej republiky, Bratislava: Slovenská akadémia vied, Slovenský úrad geodézie a kartografie.

Karte des Deutschen Reiches, 1:100 000, Einheitsblatt Nr 115 Friedland i.Schl.-Lewin., 1932: Reichsamt für Landesaufnahme.

Kondracki J., Richling A., 1994, Regiony fizycznogeograficzne, 1:1 500 000, In: Atlas Rzeczypospolitej Polskiej, Warszawa: Główny Geodeta Kraju.

Mapa topograficzna Polski, 1:10 000, sheet 494.212 Olza, 1987, Warszawa: Główny Geodeta Kraju.

Rastrowa mapa podziału hydrograficznego Polski, 1:50 000, Warszawa: Zakład Hydrografii i Morfologii Koryt Rzecznych Instytutu Meteorologii i Gospodarki Wodnej, http://mapa.kzgw.gov.pl/.

Polska. Mapa ogólnogeograficzna, 1:500 000, 2011, Warszawa: Główny Urząd Geodezji i Kartografii.

Topografická mapa, 1:25 000, sheet M-33-43-D-b (Harrachov), 1956, Generální štáb Československé lidové armády.

Topographische Karte,1:25 000 (Messtischblatt), sheet 5361 Tschöbsdorf, 1943: Reichsamt für Landesaufnahme.

Vyšši geomorfologické jednotky České republiky, 1:500 000, 1996, Praha: Český úřad zeměměřický a katastrální. 